\title{
Effects of Modified Atmosphere Packaging on Toxin Production by Clostridium botulinum in Raw Aquacultured Summer Flounder Fillets (Paralichthys dentatus)
}

\author{
FLETCHER M. ARRITT, ${ }^{1}$ JOSEPH D. EIFERT, ${ }^{1 *}$ MICHAEL L. JAHNCKE, ${ }^{2}$ MERLE D. PIERSON, ${ }^{1}$ AND \\ ROBERT C. WILLIAMS ${ }^{1}$
}

\author{
${ }^{1}$ Department of Food Science and Technology, Virginia Tech, Duck Pond Drive, Blacksburg, Virginia 24061; and \\ ${ }^{2}$ Virginia Seafood Agricultural Research and Extension Center, Virginia Tech, 102 South King Street, Hampton, Virginia 23669, USA
}

MS 06-423: Received 17 July 2006/Accepted 24 January 2007

\begin{abstract}
Packaging fishery products under vacuum atmosphere packaging (VAC) and modified atmosphere packaging (MAP) conditions can significantly extend the shelf life of raw, refrigerated fish products. There is considerable commercial interest in marketing VAC and MAP refrigerated (never frozen) raw fish fillets. The objective of this study was to determine if Clostridium botulinum toxin development precedes microbiological spoilage in raw, refrigerated flounder fillets. Aquacultured flounder (Paralichthys dentatus) individual fish fillets either were packed with a film having an oxygen transmission rate (OTR) of $3,000 \mathrm{~cm}^{3} \mathrm{~m}^{-2} 24 \mathrm{~h}^{-1}$ at $22.8^{\circ} \mathrm{C}$ or were vacuum packaged or packaged under $100 \% \mathrm{CO}_{2}$ with a film having an OTR of $7.8 \mathrm{~cm}^{3} \mathrm{~m}^{-2} 24 \mathrm{~h}^{-1}$ at $21.1^{\circ} \mathrm{C}$ and were stored at 4 and $10^{\circ} \mathrm{C}$. Samples were analyzed by aerobic plate count (APC) for spoilage and qualitatively for botulinum toxin with a mouse bioassay. The results demonstrate that flounder fillets $\left(4^{\circ} \mathrm{C}\right)$ packaged with a film having an OTR of 3,000 were microbiologically spoiled (APC, $>10^{7} \mathrm{CFU} / \mathrm{g}$ ) on day 15 , but there was no toxin formation, even after 35 days of storage. However, at $10^{\circ} \mathrm{C}$, toxin production occurred (day 8), but it was after microbial spoilage and absolute sensory rejection (day 5). Vacuum-packaged fillets and $100 \% \mathrm{CO}_{2}$ fillets $\left(4^{\circ} \mathrm{C}\right)$ packaged with a film having an OTR of 7.8 were toxic on days 20 and 25 , respectively, with microbial spoilage (APC, $>10^{7} \mathrm{CFU} / \mathrm{g}$ ) not occurring during the tested storage period (i.e., $>35$ days). At $10^{\circ} \mathrm{C}$, in vacuum-packaged flounder, toxin formation coincided with microbiological spoilage (days 8 to 9 ). In the $100 \% \mathrm{CO}_{2}$-packaged fillets, toxin formation occurred on day 9 , with microbial spoilage occurring on day 15. This study indicates that films with an OTR of 3,000 can be used for refrigerated fish fillets and still maintain the safety of the product.
\end{abstract}

The world's current consumption of seafood is approximately 80 million metric tons, with a prediction of 110 to 120 million metric tons by 2010. Harvesting, farming, and processing technologies must continue to develop to meet the increasing demand (12). Decreasing fishery supplies of wild flounder populations and an increased market demand, particularly with the cultivation of Japanese flounder, Paralichthys olivaceus (18), has resulted in increased flatfish research and production studies. In the United States, the summer flounder (Paralichthys dentatus) is a highly valued fish found off the waters of the Atlantic Coast from Nova Scotia to southern Florida (27). This species is presently being studied for its potential to be raised through aquaculture techniques.

The use of modified atmosphere packaging (MAP) and vacuum atmosphere packaging (VAC) can increase the shelf life of refrigerated fishery products (22). Nevertheless, there are food safety and quality issues that must be considered when marketing refrigerated foods, especially those with an extended shelf life. Processors should carefully evaluate and prevent hazards that may exist in refrigerated foods with an extended shelf life before marketing such

\footnotetext{
* Author for correspondence. Tel: 540-231-3658; Fax: 540-231-9293; E-mail: jeifert@vt.edu.
}

products (3). Microbiological concerns with refrigerated foods focus on psychrotrophic and mesophilic organisms that have an opportunity to grow during extended refrigerated storage. Several pathogens can grow at refrigerated temperatures, and for some pathogens, only a few cells can cause illness when ingested (17).

Shelf life is increased by the inhibition of aerobic spoilage bacteria, but VAC and MAP will not inhibit the growth of Clostridium botulinum (15). This organism has the potential to produce a powerful neurotoxin in foods, especially under anaerobic conditions. The lethal dose of botulinum toxin in adults is approximately $1 \mathrm{ng} / \mathrm{kg}$. Fish inoculated with high numbers of $C$. botulinum spores and stored under VAC or MAP conditions have become toxic within 6 to 8 days during refrigerated storage at temperatures of $50^{\circ} \mathrm{F}\left(10^{\circ} \mathrm{C}\right)(19)$. This is a concern, since in distribution and retail storage, product temperatures have been found to fluctuate between 40 and $50^{\circ} \mathrm{F}\left(4.4\right.$ to $\left.10^{\circ} \mathrm{C}\right)(19)$.

Post et al. (21) reported that flounder fillets became absolutely spoiled before toxin production. Cod fillets developed toxin before absolute rejection in all temperature and atmosphere combinations, except for 90:8:2 $\mathrm{CO}_{2}-\mathrm{N}_{2}-$ $\mathrm{O}_{2}$ packages at $26^{\circ} \mathrm{C}$, air packages at $12^{\circ} \mathrm{C}$, and air and $100 \% \mathrm{~N}_{2}$ packages at $8^{\circ} \mathrm{C}$. Toxin production coincided with absolute sensory rejection in the $26^{\circ} \mathrm{C}$ air packages. For 
whiting fillets, only air packages stored at $8^{\circ} \mathrm{C}$ were spoiled before toxin production. Spoilage coincided with toxin production at 26 and $8^{\circ} \mathrm{C}$ for vacuum and $100 \% \mathrm{~N}_{2}$ packages. All other package and temperature combinations became toxic before absolute spoilage. Conversely, in cod fillets (25), crawfish tails (16), and trout fillets (5), sensory rejection preceded toxin production for every temperature and package combination. However, Dufresne (4) reported that toxigenesis in smoked trout fillets coincided with sensory rejection at some temperatures, oxygen transmission rates (OTRs), and atmosphere combinations.

Garcia et al. (9) packaged salmon fillets in VAC and MAP. At $4^{\circ} \mathrm{C}$ storage, sensory scores indicated rejection before toxin production by the same sensory scale as used by Post et al. (21). In another study, inoculated shrimp at $4^{\circ} \mathrm{C}$ spoiled when microbial counts were approximately $6.0 \mathrm{log}$ $\mathrm{CFU} / \mathrm{g}$, but no toxin was detected (10). At $10^{\circ} \mathrm{C}$, sensory rejection occurred before microbial counts exceeded $6.0 \mathrm{log}$ $\mathrm{CFU} / \mathrm{g}$ but coincided with toxin production. Additionally, Garren et al. (11) inoculated aquacultured rainbow trout, and at $10^{\circ} \mathrm{C}$, toxin developed after spoilage. Psychrotrophic counts were $\sim 6.0 \log \mathrm{CFU} / \mathrm{g}$, and off-odors were present.

Total plate counts for packaged salmon fillets and fillet sandwiches composed of two fillets at $4.4^{\circ} \mathrm{C}$ were $9.0 \mathrm{log}$ $\mathrm{CFU} / \mathrm{g}$ at the time of absolute sensory rejection (29). Toxin was not detected in either type of packaged fillet for any temperature combination. Toxin production coincided with sensory rejection in the MAP fillets, and toxin production preceded spoilage in the air-packaged fillets at $22.2^{\circ} \mathrm{C}$. Microbial counts were approximately $9.0 \log \mathrm{CFU} / \mathrm{g}$ for fillets in air and MAP. In other studies with aquacultured tilapia, catfish, and salmon packaged in modified atmosphere, sensory rejection preceded toxin production in all scenarios, except for salmon stored at $8^{\circ} \mathrm{C}$, tilapia at $16^{\circ} \mathrm{C}$, and catfish at $16^{\circ} \mathrm{C}$, when toxin production coincided with sensory rejection. Toxin production in the salmon stored at $16^{\circ} \mathrm{C}$ preceded sensory rejection. In all cases, microbial counts were $>8.0 \log \mathrm{CFU} / \mathrm{g}(23-26)$.

Cai et al. (2) reported that inoculated and uninoculated catfish fillets spoiled at the same rate. At $4^{\circ} \mathrm{C}$ in overwrapped, packaged samples, toxin production coincided with sensory rejection but was preceded by microbiological spoilage. In MAP samples, toxin production coincided with microbiological spoilage and sensory rejection. During $10^{\circ} \mathrm{C}$ storage, toxin production occurred in overwrapped, packaged samples during or before sensory rejection but after microbial spoilage. In MAP fillets, the time of toxin production coincided with microbial spoilage but not with sensory rejection.

Eklund (6) identified the following conditions needed for foodborne illness from $C$. botulinum to occur: (i) the food must be contaminated with spores or vegetative cells; (ii) the processing treatment must be inadequate to inactivate spores or the product is recontaminated after processing; (iii) the food must support growth and toxin formation when temperatures exceed $3.3^{\circ} \mathrm{C}$; and (iv) the food is consumed without cooking or after inadequate heating to inactivate preformed toxin. C. botulinum is indigenous to the aquatic environment, and fish is an excellent substrate for growth. Spores can survive cooking, and the organism also can grow at temperatures as low as $3.3^{\circ} \mathrm{C}(8,28)$ or even at $3.0^{\circ} \mathrm{C}(13)$. The objective of this study was to determine if aquacultured flounder could be packaged in a reduced oxygen package to extend shelf life without compromising safety.

\section{MATERIALS AND METHODS}

Fillet preparation. Summer flounder ( $P$. dentatus) fillets were removed from adult fully grown finfish at the aquaculture facility of the Virginia Seafood Agricultural Research and Extension Center (Hampton, Va.). All flounder were fed the same diets under the same culture conditions and were the same age. These fish were netted from tanks and chill killed in a cooler of ice water. They remained in the cooler until they were filleted $(\sim 10 \mathrm{~min})$. Four boneless and skinless fillets were obtained from each fish ( $\sim 350 \mathrm{~g}$ total). Each fillet was rinsed quickly in tap water to remove excess blood and placed into a 1-gal (3.785-liter) resealable plastic bag, packed in ice, and transported immediately to the laboratory for packaging, storage, and analysis.

Packaging and storage. Individual fish fillets either were packed with a film having an OTR of $3,000 \mathrm{~cm}^{3} \mathrm{~m}^{-2} 24 \mathrm{~h}^{-1}$ at $22.8^{\circ} \mathrm{C}$ (Cryovac Super L Bag, Cryovac, Duncan, S.C.) or were vacuum packaged or packaged under $100 \% \mathrm{CO}_{2}$ with a film having an OTR of $7.8 \mathrm{~cm}^{3} \mathrm{~m}^{-2} 24 \mathrm{~h}^{-1}$ at $21.1^{\circ} \mathrm{C}$ (High Barrier Deli 3-mil., composed of 0.75-gauge nylon with EVOH and 2.25gauge polyethylene; Koch Supplies Inc., Kansas City, Mo.). An Ultravac vacuum packager (Koch) was used for the 3,000-OTRpackaged fish and for the vacuum-packaged fish (OTR, 7.8).

The modified atmosphere packages were prepared by flushing packages to their capacity with $100 \% \mathrm{CO}_{2}$ gas (Holox Limited, Roanoke, Va.) for four consecutive replications. A $3-\mathrm{ft}$ $(91.44-\mathrm{cm})$ Nalgene hose terminated with a 5 -in. $(12.7-\mathrm{cm}), 24$ gauge cannula delivered the modified atmosphere. The cannula was placed to one side of the package during filling and sanitized with ethanol between each package. Gas was expelled by hand from each bag three times prior to sealing. Gas was prevented from escaping by folding over the open end of the package while it was double-sealed with a portable tabletop contact heat sealer (Kapack Corp., Minneapolis, Minn.). The final gas-to-product ratio was at least 6:1. Packaged fillets were stored at 4 and $10^{\circ} \mathrm{C}$ with a minimum 1 -in. $(2.54-\mathrm{cm})$ separation between packages to allow respiration.

Spoilage studies. Prior to C. botulinum inoculation studies, aerobic, anaerobic, and psychrotrophic plate counts (in triplicate) were conducted for the 7.8- and 3,000-OTR-packaged fillets after storage at 4 and $10^{\circ} \mathrm{C}$. Sampling days were selected on the basis of $0,75,100$, and $125 \%$ of estimated shelf life. In this study, microbiological spoilage (end of shelf life) was defined as at least $7.0 \mathrm{log} \mathrm{CFU} / \mathrm{g}$ for any plate count analysis (14). Samples were pulverized in a laboratory stomacher (Seward Stomacher $400 \mathrm{Cir}-$ culator, Seward, Thetford, Norfolk, UK) for $2 \mathrm{~min}$ at $230 \mathrm{rpm}$ with a 1:4 ratio $(\mathrm{wt} / \mathrm{vol})$ of sample to Butterfield's buffer (International BioProducts, Bothell, Wash.). One milliliter of sample was serially diluted with Butterfield's buffer and then plated onto Aerobic Plate Count (APC) Petrifilm (3M Microbiology, St. Paul, Minn.) in duplicate. Petrifilm plates were incubated for $48 \mathrm{~h}$ at $36^{\circ} \mathrm{C}$, except for psychrotrophic films, which were incubated for 3 to 4 days at $21^{\circ} \mathrm{C}$. These spoilage studies provided shelf life estimations that were used to reduce the frequency of sampling for the inoculation and toxin determination studies. 
Headspace gas analysis. Headspace was sampled with a 30 ml syringe (Becton Dickinson, Franklin Lakes, N.J.) having an air valve and a 1-in. (2.54-cm), 21-gauge needle (Becton Dickinson) inserted into each package through a $1 / 2$-in. $(1.27-\mathrm{cm}) \mathrm{sec}-$ tion of $1 / 4-$ in. $(0.63-\mathrm{cm})$-thick adhesive weather stripping. An Illinois Instruments 6600 Headspace Oxygen/Carbon Dioxide Analyzer (Illinois Instruments, Ingleside, Ill.) was used to analyze the headspace composition of two packages each of aerobic and $100 \% \mathrm{CO}_{2}$ packs stored at each temperature for several selected storage times.

pH determination. Packages used for headspace gas analysis were also used for $\mathrm{pH}$ determination. Fillets were removed and cut open, and a 1:1 ratio of high-pressure liquid chromatographic grade water (VWR International, West Chester, Pa.) was added. The samples were hand massaged and further macerated with a laboratory stomacher (Seward Stomacher 400 Circulator) for 2 min at $230 \mathrm{rpm}$. The $\mathrm{pH}$ was measured with an Accumet $\mathrm{pH}$ meter 915 (Fisher Scientific Company, St. Louis, Mo.) by a Symphony $\mathrm{pH}$ electrode (VWR).

Spore inoculation. Five strains of nonproteolytic $C$. botulinum-17 Type B, Beluga, Minnesota, Alaska Type E, and Type F 83F-were obtained from the culture collection of the Department of Food Science and Technology at Virginia Tech, and spore crops were created by biphasic procedures as described in Anellis et al. (1). Spores were harvested by removing $10 \mathrm{ml}$ of the liquid phase and combining it with $10 \mathrm{ml}$ of sterile Butterfield's buffer (International BioProducts). The subsequent suspension was centrifuged with a Sorvall RC-5B refrigerated centrifuge (DuPont Instruments, Wilmington, Del.) at $2,420 \times g$ for $20 \mathrm{~min}$ at $4^{\circ} \mathrm{C}$. The supernatant was removed, and the spores were resuspended with $10 \mathrm{ml}$ of sterile Butterfield's buffer and centrifuged again. This process was repeated three consecutive times before $10-\mathrm{ml}$ aliquots of washed spores were placed into sterile glass vials and stored at $-80^{\circ} \mathrm{C}$ until needed.

Spore crops were enumerated with serial dilutions in sterile Butterfield's buffer and anaerobically incubated in Trypticasepeptone-glucose-yeast extract roll tubes. Tubes were incubated for up to 10 days at $30^{\circ} \mathrm{C}$. Final equivalent dilutions were made with sterile Butterfield's buffer to produce a five-strain cocktail in a concentration of 2.0 to $3.0 \log \mathrm{CFU} / \mathrm{ml}$ and then stored in vials at $-80^{\circ} \mathrm{C}$ until needed. Purity of cultures was confirmed by identifying rainbow iridescent or pearly reactions on anaerobically incubated McClung-Toabe egg yolk agar at $30^{\circ} \mathrm{C}$ (7).

During the thawing process, manual shaking of the frozen cocktail cultures at room temperature with sterilized glass beads was used to break apart any coagulated spores (7). An external inoculation of approximately 2.0 to $3.0 \mathrm{log} \mathrm{CFU} / \mathrm{g}$ of nonheatshocked spores was applied by dropwise addition with a 1-ml tuberculin syringe (Becton Dickinson) on the outside (bone side) of each fillet. The distribution was applied by spreading the droplets with a sterile L-shaped glass rod into a thin layer (19). Nonheat-shocked spores were used, since environmental temperatures during raw fish fillet processing are well below those required to heat shock spores $\left(80^{\circ} \mathrm{C}\right)$. Between inoculations, the thawed cocktail was stored in ice packs to prevent the mixture from warming. Sterile distilled water inoculations were used as a control. Five to seven replications of all temperature and packaging combinations were performed.

Toxin determination and APC. Detection of C. botulinum toxin and APC followed the general protocol outlined in the U.S. Food and Drug Administration Bacteriological Analytical Manual (30). Samples were pulverized in a laboratory stomacher for 2
TABLE 1. Sensory rating definitions for aquacultured flounder fillets $^{a}$

\begin{tabular}{ccc}
\hline Rating & Appearance & Odor \\
\hline 1 & $\begin{array}{c}\text { Flesh firm, totally trans- } \\
\text { lucent to totally } \\
\text { opaque, color light to } \\
\text { dark varying shades of } \\
\text { pink }\end{array}$ & Little or no odor \\
& & \\
& Flesh firm, slight darken- & Slight fishy odor \\
& ing in color & \\
& Flesh firm, off colors evi- & Fishy or slight off-odor, \\
& dent (yellow, green, & not objecitonable \\
& and gray) & Noticeable odor, strong \\
& Tissue deterioration evi- & fishy off-odor \\
& dent, definite darkening & of color \\
& Definite tissue break- & Putrid, trashlike odor, \\
& down, flesh dark & strong musty odor \\
\hline
\end{tabular}

${ }^{a}$ Variation of table in Post et al. (21).

min at $230 \mathrm{rpm}$ with a 1:1 ratio of gel phosphate buffer, with $\mathrm{pH}$ adjusted to 6.2 with $1 \mathrm{~N} \mathrm{NaOH}$ or $\mathrm{HCl}$. One milliliter of sample was serially diluted into Butterfield's buffer, plated onto Petrifilm $(3 \mathrm{M})$ in duplicate, and incubated for $48 \mathrm{~h}$ at $36^{\circ} \mathrm{C}$. Microbiological spoilage was defined as at least $7.0 \log \mathrm{CFU} / \mathrm{g}$ for APC analysis (14). Twenty milliliters of slurry was removed and centrifuged for $10 \mathrm{~min}$ at $11,951 \times \mathrm{g}$. The supernatant was filtered with a sterile, 25-mm-diameter, 0.2- $\mu \mathrm{m}$-pore-size syringe-tip filter (Acrodisk, Gelman Laboratory, East Hills, N.Y.). Samples were typically frozen $\left(-20^{\circ} \mathrm{C}\right)$ at this point. The freezing process, as well as the dilution and filtering, was used to reduce the event of nonspecific death in the mouse biotoxin assay due to the presence of additional toxic compounds in severely spoiled fillets (15). Within 7 days, samples were thawed at $4^{\circ} \mathrm{C}$. Trypsin solution $(0.2 \mathrm{ml})$ was added to two 1.8-ml aliquots of supernatant for each sample. The subsequent treated solutions were incubated at 35 to $37^{\circ} \mathrm{C}$ with gentile agitation for $1 \mathrm{~h}$. One aliquot was heated to $100^{\circ} \mathrm{C}$ for 30 min as a control. One milliliter of trypsinized, nontrypsinized, and heated trypsinized supernatant was loaded into three separate tuberculin syringes. Five 15- to 18-g male mice (Mus musculus) (Harlan Sprague Dawley) were given an intraperitoneal injection with $0.5 \mathrm{ml}$ of supernatant (either trypsinized [two], nontrypsinized [two], or control [one]). Mice were observed periodically for symptoms of botulism for $48 \mathrm{~h}$. Botulism signs typically began within the first $24 \mathrm{~h}$ with ruffling of fur, followed in sequence by labored breathing, weakness of limbs, total paralysis with gasping for breath, and finally death due to respiratory failure. Any mice not succumbing to the effects of the toxin were sacrificed with $\mathrm{CO}_{2}$ gas. Storage temperatures and sampling days were identical to those used for $\mathrm{pH}$ determination, except that five to seven replications were performed with APC, toxin determination, and sensory evaluation.

Sensory evaluation. Sensory analysis was performed in conjunction with the microbiological and toxin analysis. The fillets were held frozen $\left(-80^{\circ} \mathrm{C}\right)$ until the day of the sensory analysis. Samples were thawed at room temperature, allowed to equilibrate at $4^{\circ} \mathrm{C}$, and presented as whole fillets to three untrained panelists, who were immunized against $C$. botulinum toxin. The panelists held packaged fish samples a minimum distance of 8 in. (20.32 $\mathrm{cm}$ ) from the nose. A five-point hedonic scale was used to determine characteristics of odor and appearance (see Table 1). Normal 


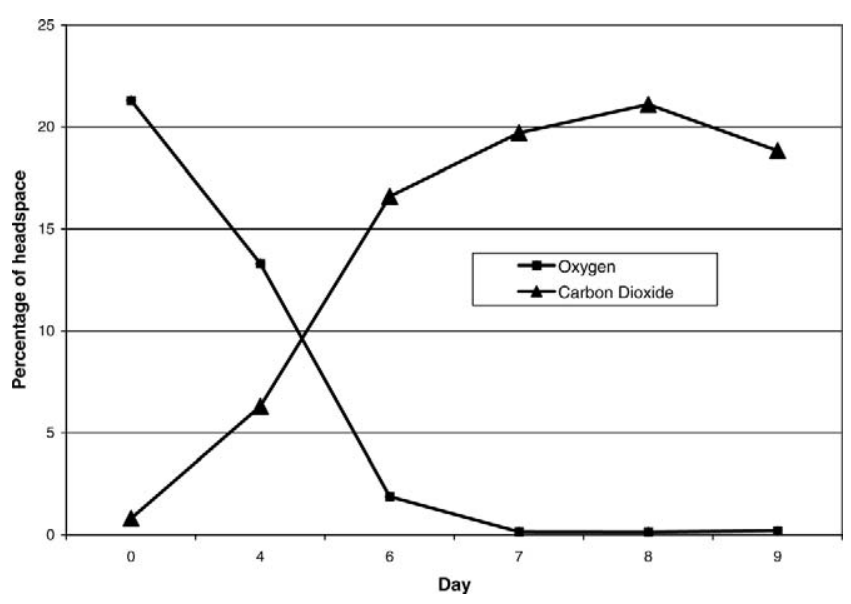

FIGURE 1. Aerobic package headspace gas analysis at $10^{\circ} \mathrm{C}$ for aquacultured flounder. Film oxygen transmission rate (OTR): $3,000 \mathrm{~cm}^{3} \mathrm{~m}^{-2} 24 \mathrm{~h}^{-1}$ at $22.8^{\circ} \mathrm{C}$.

rejection was given a numerical value of 4 , while a score of 5 was reserved for a product that had deteriorated to the point of absolute rejection, i.e., if the consumers had purchased it and were starving to death, they would not consider consumption (21).

\section{RESULTS AND DISCUSSION}

Headspace gas. The average gas-to-product ratio for air and $100 \% \mathrm{CO}_{2}$ packages was 6:1. In uninoculated packaged fillets $\left(3,000\right.$-OTR film) at $10^{\circ} \mathrm{C}, \mathrm{O}_{2}$ concentrations initially were $21.3 \%$ but dropped to $<1.0 \%$ by day 6 . Initial concentrations of $\mathrm{CO}_{2}$ were $0.8 \%$ but increased to $16.6 \%$ by day 6 and peaked on day 8 at $21.1 \%$ (Fig. 1). For $100 \%$ $\mathrm{CO}_{2}$-packaged fillets, the concentration of $\mathrm{CO}_{2}$ at 10 and $4^{\circ} \mathrm{C}$ remained at $100 \%$ until the termination of the study on days 18 and 35, respectively. Initially, there was a small decrease in the total volume of the $100 \% \mathrm{CO}_{2}$ packages, which was caused by gas being absorbed into the tissue, particularly at $4^{\circ} \mathrm{C}$. This partial deflation was also described by Garcia et al. (9) in both $100 \% \mathrm{CO}_{2}$ and 70:30 $\mathrm{CO}_{2}-\mathrm{N}_{2}$ (modified atmosphere) packages at different temperature combinations.

On day 20 at $4^{\circ} \mathrm{C}, \mathrm{O}_{2}$ concentrations in uninoculated packaged fillets $(3,000$-OTR film) were $<1.0 \%$ from an initial concentration of $21.3 \%$. The concentration fluctuated very little during the remainder of the study, which ended on day 35. The $\mathrm{CO}_{2}$ concentration for the same packages increased from 0.8 to $21.3 \%$ by day 20 and achieved a concentration of $22.3 \%$ by day 35 . Changes in the composition of headspace gases are attributable to postmortem metabolic and microbial processes. In similar studies, $\mathrm{O}_{2}$ concentrations dramatically decreased in tilapia fillets (23), aquacultured salmon (26), pond-raised catfish (24), and cod (25). Headspace $\mathrm{CO}_{2}$ concentrations increased from $<1.0$ to $>15.0 \%$ at the time of spoilage in all four studies. Concentrations of $\mathrm{CO}_{2}$ and $\mathrm{O}_{2}$ for channel catfish packaged in modified atmosphere with 80:20 $\mathrm{CO}_{2}-\mathrm{O}_{2}$ remained relatively constant (2). Garcia et al. (9) also reported an initial decrease in headspace concentration for $\mathrm{CO}_{2}$ in both $100 \%$ $\mathrm{CO}_{2}$ and 70:30 $\mathrm{CO}_{2}-\mathrm{N}_{2}$ (modified atmosphere) packages. Conversely, Stier et al. (29) reported that for salmon fillets stored under 60:25:15 $\mathrm{CO}_{2}-\mathrm{O}_{2}-\mathrm{N}_{2}, \mathrm{CO}_{2}$ concentrations de- clined from approximately $60 \%$ to approximately $20 \%$; however, the $\mathrm{O}_{2}$ concentrations reacted differently from those in previously mentioned articles, increasing to approximately $30 \%$ and then decreasing to approximately $10 \%$. Dufresne et al. (5) reported that, in rainbow trout packaged and back flushed with 85:15 $\mathrm{CO}_{2}-\mathrm{N}_{2}$ having OTRs of $4,371,4,923$, and $10,043 \mathrm{~cm}^{3} \mathrm{~m}^{-2} 24 \mathrm{~h}^{-1}$ at $24^{\circ} \mathrm{C}$ and $0 \%$ relative humidity, there was a headspace decrease in $\mathrm{CO}_{2}$ and an increase in $\mathrm{O}_{2}$, but for packaging with an OTR of $11.6 \mathrm{~cm}^{3} \mathrm{~m}^{-2} 24 \mathrm{~h}^{-1}$ at $24^{\circ} \mathrm{C}$ and $0 \%$ relative humidity, a headspace decrease in $\mathrm{O}_{2}$ and an increase in $\mathrm{CO}_{2}$ were recorded.

Fillet pH. Initial $\mathrm{pH}$ values in uninoculated flounder fillets at 4 and $10^{\circ} \mathrm{C}$ for both the 3,000-OTR-packaged fillets and the $100 \% \mathrm{CO}_{2}$-packaged fillets (OTR, 7.8) averaged 6.76 . At $10^{\circ} \mathrm{C}, \mathrm{pH}$ values slowly declined in the 3,000OTR-packaged fillets to 6.16 by day 9 , coinciding with absolute rejection. For the $100 \% \mathrm{CO}_{2}$-packaged fillets, $\mathrm{pH}$ values decreased to 6.03 by day 9 , which is where the values generally remained until the termination of the study on day 18. The initial pH measurement for the 3,000-OTRpackaged fillets at $4^{\circ} \mathrm{C}$ (day 20) averaged 6.35. Subsequent measurements were higher but were less than 6.7. Fillets packaged in $100 \% \mathrm{CO}_{2}$ were initially sampled on day 20 , with an average $\mathrm{pH}$ value of 6.00 . The $\mathrm{pH}$ increased to approximately 6.3 by the termination of the study on day 35 .

Parkin et al. (20) found a decrease in $\mathrm{pH}$ for MAP rockfish fillets packaged in $80: 20 \mathrm{CO}_{2}-\mathrm{O}_{2}$. Reddy et al. (25) and Cai et al. (2) found no change in the $\mathrm{pH}$ of the cod and channel catfish fillets stored at any temperature or atmosphere combination, respectively. Additionally, Dufresne et al. (5) reported no significant changes in the $\mathrm{pH}$ of the rainbow trout fillets due to the buffering capacity of the fish proteins. Similarly, there was no initial decrease in the $\mathrm{pH}$ of the salmon fillets stored under $100 \% \mathrm{CO}_{2}$ (9). Conversely, Reddy et al. (24) reported that the initial average surface $\mathrm{pH}$ for catfish fillets on the day of spoilage in air packages at 4 and $16^{\circ} \mathrm{C}$ increased but that it decreased at $8^{\circ} \mathrm{C}$. In modified atmosphere packages, $\mathrm{pH}$ values decreased and then increased above initial levels by the day of spoilage. For all combinations of package and temperature for aquacultured tilapia (23) and salmon fillets (26), surface $\mathrm{pH}$ values decreased during early storage and increased later. The initial $\mathrm{pH}$ decrease was assumed to be caused by the saturation of $\mathrm{CO}_{2}$ into the tissue of the fillet during early storage. However, for all atmosphere combinations and types of species, $\mathrm{pH}$ values ranged from 6.12 to 7.04. In uninoculated air-packaged salmon fillets, $\mathrm{pH}$ values increased by 0.05 to 0.12 at 4,8 , and $16^{\circ} \mathrm{C}$.

Toxin production in relation to microbiological count and sensory rejection. At $4^{\circ} \mathrm{C}$, inoculated flounder spoiled in the 3,000-OTR package after 15 days, but no toxin was formed, even after 35 days of storage (Tables 2 and 3). At $10^{\circ} \mathrm{C}$, botulinum toxin occurred in inoculated flounder fillets in the 3,000-OTR-packaged fillets on day 8 of the seventh replication and on day 9 in one of five replications (Table 3). (Note: The National Advisory Committee on Microbiological Criteria for Foods (19) report recommends five replications 
TABLE 2. Microbial spoilage and botulinum toxin development in raw flounder fillets

\begin{tabular}{llcc}
\hline Storage temp & Packaging & $\begin{array}{c}\text { Approx days } \\
\text { to microbial } \\
\text { spoilage }^{a}\end{array}$ & $\begin{array}{c}\text { Initial day of } \\
\text { toxin detection }\end{array}$ \\
\hline $39^{\circ} \mathrm{F}\left(4^{\circ} \mathrm{C}\right)$ & Aerobic & 15 & $>35^{b}$ \\
& Vacuum & $>35$ & $20^{c}$ \\
$50^{\circ} \mathrm{F}\left(10^{\circ} \mathrm{C}\right)$ & $100 \% \mathrm{CO}_{2}$ & $>37$ & $25^{d}$ \\
& Aerobic & 5 & 8 \\
& Vaccuum & 9 & 9 \\
& $100 \% \mathrm{CO}_{2}$ & 9 & $9^{c}$ \\
\hline
\end{tabular}

a $\mathrm{APC}, \geq 7.0 \log \mathrm{CFU} / \mathrm{g}$.

${ }^{b}$ No samples were analyzed for toxin after day 35 .

${ }^{c}$ Toxin may have developed prior to this day.

${ }^{d}$ Toxicity occurred in one of seven replications. For this replication, storage temperature on day 20 increased to 48 to $52^{\circ} \mathrm{F}$ ( 9 to $\left.11^{\circ} \mathrm{C}\right)$ for $48 \mathrm{~h}$ before returning to $39^{\circ} \mathrm{F}\left(4^{\circ} \mathrm{C}\right)$.

for this type of study.) However, at $10^{\circ} \mathrm{C}$, both microbial spoilage (Table 2) and absolute sensory rejection (data not shown) occurred before toxin formation.

At $4^{\circ} \mathrm{C}$ in vacuum-packaged fillets (OTR, 7.8), toxin formed on or before day 20, but microbial spoilage did not occur for more than 35 days (Tables 2 and 3). At $10^{\circ} \mathrm{C}$ in vacuum-packaged fillets (OTR, 7.8) on day 9, toxin formation coincided with microbial spoilage (Tables 2 and 3). However, sensory panelists did not reject the fillets on the basis of odor or appearance (data not shown).

At $4^{\circ} \mathrm{C}$ in $100 \% \mathrm{CO}_{2}$-packaged fillets (OTR, 7.8), toxin formed in one of seven replications sampled on days 25 , 30 , and 35 . This may have been caused by an incubator malfunction on day 20, when the temperature reached 9 to $11^{\circ} \mathrm{C}$ for $48 \mathrm{~h}$ before the malfunction was corrected. Toxin formed, but microbial spoilage in these samples did not occur ( $>37$ days) (Table 2). This illustrates that variations in temperature, which do occur in both retail and consumer situations, can cause unsafe fillets when fillets are packaged with $100 \% \mathrm{CO}_{2}$. At $10^{\circ} \mathrm{C}$ after 9 days of storage in $100 \%$ $\mathrm{CO}_{2}$, toxin production coincided with microbial spoilage (7.8 $\log \mathrm{CFU} / \mathrm{g}$ ), since toxin formed on or before day 9 (Table 3). The APC was determined for the majority of samples, under all storage conditions, when toxin was detected. The mean APC for these samples was $7.6 \log \mathrm{CFU} / \mathrm{g}$ (range, 6.8 to $8.3 \log \mathrm{CFU} / \mathrm{g}$ ).

C. botulinum toxin production varies among fish species. Some species are more inclined to become toxic than others. Fat and protein content may play a role (25), in addition to natural microbial flora. Also, C. botulinum is sensitive to microenvironments. Because of the potency of the toxin, only a small number of spores are sufficient to cause illness. If these spores are subjected to conditions conducive to growth on the microscopic level, germination and subsequent toxin formation will occur, no matter what the package environment, microbial count, or $\mathrm{pH}$ is on the macroscopic level.

The range of $\mathrm{pH}$ values reported is consistent with those published elsewhere. Differences in initial $\mathrm{pH}$ values and final $\mathrm{pH}$ values may be attributed to factors such as
TABLE 3. Fraction of flounder fillet samples in which botulinum toxin was detected after storage at either 4 or $10^{\circ} \mathrm{C}$

\begin{tabular}{|c|c|c|c|c|}
\hline $\begin{array}{c}\text { Storage } \\
\text { temp }\left({ }^{\circ} \mathrm{C}\right)\end{array}$ & Film OTR $^{a}$ & Atmosphere & $\begin{array}{l}\text { Days of } \\
\text { storage }\end{array}$ & $\begin{array}{l}\text { No. of toxin } \\
\text { detected/no. } \\
\text { of replications }\end{array}$ \\
\hline \multirow[t]{4}{*}{4} & 3,000 & Aerobic & 20 & $0 / 7$ \\
\hline & & & 25 & $0 / 5$ \\
\hline & & & 30 & $0 / 5$ \\
\hline & & & 35 & $0 / 5$ \\
\hline \multirow[t]{5}{*}{10} & 3,000 & Aerobic & 4 & $0 / 5$ \\
\hline & & & 6 & $0 / 5$ \\
\hline & & & 7 & $0 / 5$ \\
\hline & & & 8 & $1 / 7$ \\
\hline & & & 9 & $1 / 5$ \\
\hline \multirow[t]{4}{*}{4} & 7.8 & Vacuum & 20 & $2 / 5$ \\
\hline & & & 25 & $1 / 7$ \\
\hline & & & 30 & $2 / 7$ \\
\hline & & & 35 & $2 / 7$ \\
\hline \multirow[t]{4}{*}{10} & 7.8 & Vacuum & 7 & $0 / 5$ \\
\hline & & & 9 & $2 / 5$ \\
\hline & & & 10 & $4 / 5$ \\
\hline & & & 11 & $5 / 7$ \\
\hline \multirow[t]{4}{*}{4} & 7.8 & $100 \% \mathrm{CO}_{2}$ & 20 & $0 / 5$ \\
\hline & & & 25 & $1 / 7^{b}$ \\
\hline & & & 30 & $1 / 7^{b}$ \\
\hline & & & 35 & $1 / 7^{b}$ \\
\hline \multirow[t]{5}{*}{10} & 7.8 & $100 \% \mathrm{CO}_{2}$ & 9 & $4 / 5$ \\
\hline & & & 12 & $2 / 5$ \\
\hline & & & 15 & $4 / 7$ \\
\hline & & & 17 & $4 / 7$ \\
\hline & & & 18 & $5 / 7$ \\
\hline
\end{tabular}

a Oxygen transmission rate (OTR): $3,000 \mathrm{~cm}^{3} \mathrm{~m}^{-2} 24 \mathrm{~h}^{-1}$ at $22.8^{\circ} \mathrm{C}$ or $7.8 \mathrm{~cm}^{3} \mathrm{~m}^{-2} 24 \mathrm{~h}^{-1}$ at $21.1^{\circ} \mathrm{C}$.

${ }^{b}$ Toxin developed in one replication when the storage temperature on day 20 increased to 9 to $11^{\circ} \mathrm{C}\left(48\right.$ to $52^{\circ} \mathrm{F}$ ) for $48 \mathrm{~h}$.

different fish species, surface versus internal $\mathrm{pH}$ measurement, packaging atmospheres, relative fish freshness, and fish stress (e.g., amount of lactic acid in the musculature at time of death). Results indicate that $\mathrm{pH}$ is a poor indicator of microbial spoilage, time to sensory rejection, and toxin production. APCs (spoilage) cannot be used as a reliable tool to monitor toxin production, since there is no correlation between toxin formation and these counts.

The position of the U.S. Food and Drug Administration is that only films with an OTR greater than 10,000 can be considered oxygen permeable for packaged, refrigerated, fishery products (31). The present study indicates that lower OTR films (e.g., 3,000 OTR) can be used and considered oxygen permeable and maintain the safety of the product. At $4^{\circ} \mathrm{C}$, toxin did not form in any flounder fillet package with a film OTR of 3,000 . At $10^{\circ} \mathrm{C}$, inoculated flounder packaged with a film OTR of 3,000 did not form toxin in any replication prior to microbial spoilage or absolute sensory rejection of the product.

\section{ACKNOWLEDGMENTS}

Funding support for this project was provided by Virginia Sea Grant, National Fisheries Institute, the World Food Logistics Organization, and the International Association of Refrigerated Warehouses. 


\section{REFERENCES}

1. Anellis, A., D. Berkowitz, D. Kemper, and D. Rowley. 1972. Production of types A and B spores of Clostridium botulinum by the biphasic method: effect on spore population, radiation resistance, and toxigenicity. Appl. Microbiol. 23:734-739.

2. Cai, P., M. A. Harrison, Y. W. Huang, and J. L. Silva. 1997. Toxin production by $C$. botulinum type $\mathrm{E}$ in packaged channel catfish. $J$. Food Prot. 60:1358-1363.

3. Doyle, M. P. 1998. Extending the shelf life of refrigerated foods: for better or worse? Food Technol. 52:20.

4. Dufresne, I. 2000. Shelf life and safety studies on rainbow trout fillets packaged under modified atmospheres. M.S. thesis. MacDonald Campus of McGill University, Montreal

5. Dufresne, I., J. P. Smith, N. L. Jiun, and I. Tarte. 2000. Effect of headspace oxygen and films of different oxygen transmission rates on toxin production by Clostridium botulinum type $\mathrm{E}$ in rainbow trout fillets stored under modified atmospheres. J. Food Saf. 20:157_ 175.

6. Eklund, M. W. 1993. Clostridium botulinum, p. 209-232. In A. W. H. Hauschild and K. L. Dodds (ed.), Ecology and control in foods. Marcel Dekker, Inc., New York.

7. Eklund, M. W. 2002. Personal communication.

8. Eklund, M. W., D. I. Wieler, and F. T. Poysky. 1967. Outgrowth and toxin production of non-proteolytic type B Clostridium botulinum at 3.3 to 5.6 degrees C. J. Bacteriol. 93:1461-1462.

9. Garcia, W. G., C. Genigeorgis, and S. Lindroth. 1987. Risk of growth and toxin production by $C$. botulinum nonproteolytic types B, E and $\mathrm{F}$ in salmon fillets stored under modified atmospheres at low and abused temperatures. J. Food Prot. 50:330-336.

10. Garren, D. M., M. A. Harrison, and Y. W. Huang. 1994. Clostridium botulinum type $\mathrm{E}$ outgrowth and toxin production in vacuum-skin packaged shrimp. Food Microbiol. 11:467-472.

11. Garren, D. M., M. A. Harrison, and Y. W. Huang. 1995. Growth and production of toxin of $C$. botulinum type $\mathrm{E}$ in rainbow trout under various storage conditions. J. Food Prot. 58:863-866.

12. Garrett, E. S., M. L. Jahncke, and R. E. Martin. 2000. Applications of HACCP principles to address food safety and other issues in aquaculture: an overview. J. Aquacult. Food Prod. Technol. 9:5-20.

13. Graham, A. F., D. R. Mason, F. J. Maxwell, and M. W. Peck. 1997. Effect of $\mathrm{pH}$ and $\mathrm{NaCl}$ on growth from spores of non-proteolytic $C$. botulinum at chill temperature. Lett. Appl. Microbiol. 24:95-100.

14. International Commission on Microbiological Specifications for Foods (ICMSF). Microorganisms in foods. 2. Sampling for microbial analysis: principle and specific applications, p. 92-104. University of Toronto Press, Toronto.

15. International Commission on Microbiological Specifications for Foods (ICMSF). 1996. Clostridium botulinum, p. 66-111. In Microorganisms in foods. 5. Microbiological specifications for food pathogens. Blackie Academic \& Professional, London.

16. Lyon, W. J., and C. S. Reddmann. 2000. Bacteria associated with processed crawfish and potential toxin production by Clostridium botulinum type $\mathrm{E}$ in vacuum-packaged and aerobically packaged crawfish tails. J. Food Prot. 63:1687-1696.

17. Marth, E. H. 1998. Extended shelf life refrigerated foods: microbiological quality and safety. Food Technol. 52:57-62.

18. Matsuoka, S. 1995. A review of the nursery and growout culture techniques for the flounder (Paralichthys olivaceus) in Japan, $\mathrm{p}$. 139-145. In K. L. Main and C. Rosenfeld (ed.), Culture of highvalue marine fishes in Asia and the United States. The Oceanic Institute, Honolulu.

19. National Advisory Committee on Microbiological Criteria for Foods (NACMCF). 1992. Vacuum or modified atmosphere packaging for refrigerated raw fishery products. Report of the NACMCF. Adopted 20 March 1992. NACMCF, U.S. Food and Drug Administration, Washington, D.C.

20. Parkin, K. L., and W. D. Brown. 1982. Preservation of seafood with modified atmospheres, p. 453-465. In R. E. Martin, G. J. Flick, C. E. Hebard, and D. R. Ward (ed.), Chemistry and biochemistry of marine food products. Van Nostrand Reinhold/AVI, New York.

21. Post, L. S., D. A. Lee, M. Solberg, D. Furgang, J. Specchio, and C. Graham. 1985. Development of botulinal toxin and sensory deteri oration during storage of vacuum and modified atmosphere packaged fish fillets. J. Food Sci. 50:990-996.

22. Reddy, N. R., D. J. Armstrong, E. J. Rhodehamel, and D. A. Kautter 1992. Shelf-life extension and safety concerns about fresh fishery products, packaged under modified atmospheres: a review. $J$. Food Saf. 12:87-118

23. Reddy, N. R., A. Paradis, M. G. Roman, H. M. Solomon, and E. J. Rhodehamel. 1996. Toxin development by $C$. botulinum in modified atmosphere-packaged fresh tilapia fillets during storage. $\underline{\text { J. Food }}$ Sci. 61:632-635.

24. Reddy, N. R., M. G. Roman, M. Villanueva, H. M. Solomon, D. A. Kautter, and E. J. Rhodehamel. 1997. Shelf life and C. botulinum toxin development during storage of modified atmosphere-packaged fresh catfish fillets. J. Food Sci. 62:878-884.

25. Reddy, N. R., H. M. Solomon, and E. J. Rhodehamel. 1999. Comparison of margin of safety between sensory spoilage and onset of C. botulinum toxin development during storage of modified atmosphere (MA)-packaged fresh marine cod fillets with MA-packaged aquacultured fish fillets. J. Food Saf. 19:171-183.

26. Reddy, N. R., H. M. Solomon, H. Yep, M. G. Roman, and E. J. Rhodehamel. 1997. Shelf life and toxin development by C. botulinum during storage of modified atmosphere-packaged fresh aquacultured salmon fillets. J. Food Prot. 60:1055-1063.

27. Rogers, S. G., and M. J. Van den Avyle. 1983. Species profiles: life histories and environmental requirements of coastal fishes and invertebrates (south-Atlantic) summer flounder. FWS/OBS-82/11.15, TREL-82-4. U.S. Fish and Wildlife Service, Washington, D.C. 14 p.

28. Schmidt, C. F., R. V. Lechowich, and J. F. Folinazzo. 1961. Growth and toxin production by type E Clostridium botulinum below $4{ }^{\circ} \mathrm{C}$ J. Food Sci. 25:626.

29. Stier, R. F, L. Bell, K. A. Ito, B. D. Shafer, L. A. Brown, M. L. Seeger, B. H. Allen, M. N. Porcuna, and P. A. Lerke. 1981. Effect of modified atmosphere storage on C. botulinum toxigenesis and the spoilage microflora of salmon fillets. J. Food Sci. 46:1639-1642.

30. U.S. Food and Drug Administration. 1998. Clostridium botulinum, chap. 17. In Bacteriological analytical manual, 8th ed. AOAC International, Arlington, Va.

31. U.S. Food and Drug Administration. 2001. Clostridium botulinum toxin formation, chap. 13. In Fish and fisheries products hazards and controls guidance, 3rd ed. U.S. Food and Drug Administration. Available at: http://www.cfsan.fda.gov/ comm/haccp4.html. Accessed 1 February 2006 